\title{
Evolutionary analysis of innovation and entrepreneurship: Sidney G. Winter-recipient of the 2015 Global Award for Entrepreneurship Research
}

\author{
Ammon J. Salter • Maureen McKelvey
}

Accepted: 17 January 2016/Published online: 15 February 2016

(C) The Author(s) 2016. This article is published with open access at Springerlink.com

\begin{abstract}
This article reviews the intellectual contributions of Professor Sidney G. Winter, who is the recipient of the 2015 Global Award for Entrepreneurship Research. Professor Winter has contributed through his theoretical as well as empirical understanding of Schumpeterian processes of dynamic competition, the generation of differential technological opportunities through appropriability conditions and the mechanisms driving dynamic capabilities in firms. His work, especially the joint work on evolutionary economics with Richard R. Nelson, has led to a revival of interest in theories based upon Schumpeterian economics within the study of both entrepreneurship and innovation. His work on dynamic capabilities has been highly influential in management. Professor Sidney G. Winter is Deloitte and Touche Professor Emeritus of Management, The Wharton School, University of Pennsylvania.
\end{abstract}

Keywords Entrepreneurship - Innovation ·

Schumpeter $\cdot$ Evolutionary economics

A. J. Salter

School of Management, University of Bath,

Claverton Down, Bath BA2 7AY, UK

e-mail: a.j.salter@bath.ac.uk

M. McKelvey $(\square)$

Department of Economy and Society, Institute of Innovation and Entrepreneurship, University of Gothenburg, P.O. Box 625, 40530 Gothenburg, Sweden

e-mail: Maureen.mckelvey@handels.gu.se
JEL Classifications $\quad \mathrm{B} 52 \cdot \mathrm{L} 26 \cdot \mathrm{O} 3$

\section{Introduction}

Professor Sidney G. Winter has made significant intellectual contributions to a broader understanding of entrepreneurship by linking the internal routines and capabilities of the firm to a dynamic environment through an evolutionary approach, for which he was awarded the 2015 Global Award for Entrepreneurship Research. ${ }^{1}$ Professor Winter is one of the most outstanding scholars in the field of innovation and entrepreneurship. His work has inspired a new generation of research on the underpinning dynamics of economic development, reigniting interest in Schumpeterian economics. He has also made a major contribution to management by exploring the nature

\footnotetext{
1 The Global Award is a direct continuation of the International Award for Entrepreneurship and Small Business Research first launched in 1996 by The Swedish Entrepreneurship Forum (then Foundation for Small Business Research, FSF) and the Swedish Agency for Economic and Regional Growth. The partners behind the Award are the founder, Swedish Entrepreneurship Forum (Entreprenörskapsforum), the co-founder, the Research Institute of Industrial Economics (IFN), the sponsor, VINNOVA, and the donor, industrialist Melker Schörling. The three organizations are jointly responsible for the Award. The prize consists of 100,000 euro and a statuette by the internationally renowned sculpture Carl Milles, the "Hand of God".
} 
of firm's capabilities and how these capabilities enable (or retard) firm growth and renewal.

Winter has thus had an outstanding impact on entrepreneurship research as well as economics and management literature more broadly, throughout his career, with three distinct but overlapping phases. The first phase, which underlies much of his thinking about evolutionary processes, has to do with heterogeneity in firm behavior, and how if accepted this view would affect the traditional view of profit maximization in economics.

The second phase involved a focus upon technical change in firms as well as a development of the evolutionary economics perspective. The aim is to understand technical change within firms, as related to innovations, organizational routines and renewal. The conceptualization of evolutionary economics was done jointly with Richard R. Nelson. Their work makes a major contribution in providing a framework for Schumpeterian processes of industrial change occurs, drawing upon heterogeneity, routines and learning at the firm level, as well as the dynamics of economic competition. A related topic has been to analyze empirically and theoretically how and why firms act to appropriate returns under different selection environments in different industries, and yet also retain corporate coherence due to learning at the firm level. Winter's work with various colleagues has helped to develop the concept of technological opportunities, focusing upon the differences between industries. This has stimulated rich research traditions about appropriability regimes and about the role of knowledge external to the firms, including universities, in stimulating innovations. Winter has also contributed in explaining how firm learning contributes to corporate coherence in its production activities.

The third phase centers around defining how firms develop capabilities, including the relationship to replication and adaptation activities in the firm. This contribution, when set in relation to debates about routines, learning and managerial choice, provides a deeper understanding of capabilities not only in large firms but also in entrepreneurial firms.

Professor Winter's work has thus impacted our understanding of the phenomena related to key attributes and understanding entrepreneurship, through the synthesis of evolutionary economics as well as specific topics of innovation, technical change, routines and capabilities, which are all closely related within his intellectual contributions.
In a presentation of the Global Award for Entrepreneurship Research, Braunerhjelm and Henrekson (2009) stress that the award is given for original and influential research, where entrepreneurship is taken to include many relevant aspects, debates and disciplines. This embraces a broader understanding of entrepreneurship than specialized journals or conferences. Entrepreneurship can include the environment and organizations where entrepreneurship is conducted; the attributes of the entrepreneur; and the broader social and business function of an entrepreneur/entrepreneurship in society and the economy. Carlsson et al. (2013) are more specific about the linkages between micro- and macro-levels, and in defining the various connections, of what they call the "Evolving Domain of Entrepreneurship Research." The current article will focus on Winter's contributions, within this broader view of the changing nature of research on entrepreneurship. Winter's work has had a significant impact on many disciplines, including dedicated entrepreneurship research, strategic management, economics as well as technology and innovation management.

This article first provides an overview of Professor Winter's career, including a brief analysis of the citation impact of his work. This is followed by a review of his intellectual contributions through these three phases of his career. Section 3 combines the first phase of his work on profit maximization, as well as the start of the phase, focusing on his close collaboration with Richard Nelson in the development of evolutionary economics, which started in 1960s and culminated in their seminal 1982 book. Section 4 also addresses the second phase, but focuses upon his empirical contributions to our understanding of inter-industry differences with regard to technical progress, roughly covering the period 1978-1995. Section 5 on the third phase examines his contribution to our understanding of firm capabilities, spanning 1982-2013 and issues that have come to the fore in recent years in the research community. Section 6 concludes with discussion of his significant contributions.

\section{Career path as well as impact as indicated by citations}

Professor Winter's career demonstrates the broad range of his interests, especially his strong focus on the 
public policy aspects of his research. He received his academic training at Swarthmore College and Yale University, where he awarded his Ph.D. in economics in 1964. He also worked as a research economist at the RAND Corporation from 1959 till 1961 and later joined the Council of Economic Advisers for the US Government 1961-1962. Through the 1960s and 1970s, he held faculty appointments at the University of California, Berkeley and the University of Michigan. He returned to Yale in 1976 and stayed at the School of Organization and Management until 1989. He then became the Chief Economist at the US General Accounting Office ${ }^{2}$ till 1993, when he took a professorship (Deloitte and Touche Professor of Management) at The Wharton School, University of Pennsylvania. He became professor emeritus in 2008 and has remained active in research and writing, as this review will show.

He has received numerous accolades for his work, including honorary doctorates from the University of Lappeenranta, London Business School, University of Miami and Southern Denmark University. He is a Fellow of the American Association for the Advancement of Science and the Econometric Society. He has been awarded the Viipuri prize in Strategic Management. He also won the Schumpeter Prize from the International Joseph A. Schumpeterian Society in 2012, for his joint manuscript with Professors Franco Malerba, Richard Nelson and Luigi Orsenigo on history friendly modeling (http://www.iss-evec.de/ schumpeter_prize.htm). A book on this research stream is expected to appear this year.

Professor Winter has also been very active in sustaining the academic community. He co-founded the Journal of Economic Behavior and Organization in 1980 and acted as editor until 1985. He has also been an associate editor at Industrial and Corporate Change, Administrative Science Quarterly, Organization Science, Journal of Economic Theory and Behavioral Science. In addition, he has co-organized many international projects and efforts to help sustain interest in evolutionary economics and studies of technical change. Since the early 1990s, he has been a member of scientific advisory board for DRUID, which was originally called the Danish Research Unit on Industrial Dynamics, and has evolved into an

\footnotetext{
${ }^{2} \mathrm{GAO}$ was later renamed the US Government Accountability Office.
}

influential international association for research on entrepreneurship, innovation and industrial dynamics (www.druid.dk).

Throughout his career, Professor Winter has made a significant effort to help nurture and train new scholars, including doctoral students and junior faculty. In this role, he led doctoral classes at Yale and Wharton and personally supervised some of the leading scholars in the wider field of innovation and strategy. He has also participated a multitude of forums, workshops and colloquiums to support early career scholars, investing considerable time to help individuals from a broad range of countries and institutions further their research. Indeed, both of the authors of this article can personally attest to Professor Winter's dedication to this developmental role, and have benefitted at various stages of their careers from his advice and support.

Turning to Professor Winter's impact in terms of citations, it is clear that his book 1982 with Richard Nelson has become one of the central sources of inspiration in a range of fields, including strategic management, innovation studies and technology and innovation management. In 2014 alone, the book received over 1850 citations in Google Scholar, which is a testament to its sustained importance to the field of economics and management. Professor Winter's more recent papers have also had important influence on later work. His 2002 paper with Maurizio Zollo in Organization Science is the most cited in that journal since 2002 and the seventh most cited since the journal's inception in 1990. In addition, his paper in Strategic Management Journal in 2003 has over 500 citations, which makes it the second most cited paper in that journal since its publication. Professor Winter's 1977 paper with Richard Nelson is the seventh most cited paper in the history of the journal. In addition, his 1995 paper with Alvin Klevorick, Richard Levin and Richard Nelson is the twentieth most cited paper in the history of the journal.

Table 1 details his most cited publications, specifically those with more than 100 citations in Web of Science (WoS), as of May 2015.

Even though bibliometrics such as citations are no substitute in the Global Award for Entrepreneurship Research for judging scholarship as original and influential research, Table 1 demonstrates the immense impact and importance of Winter's research, across decades and across many streams of intellectual contributions. 
Table 1 Most-cited publications of Professor Winter

Highest cited works

\begin{tabular}{|c|c|}
\hline $\begin{array}{l}\text { WoS } \\
\text { citations }\end{array}$ & $\begin{array}{l}\text { Google } \\
\text { Scholar } \\
\text { citations }\end{array}$ \\
\hline 8300 & 24,140 \\
\hline 1220 & 4250 \\
\hline 997 & 3978 \\
\hline 663 & 2767 \\
\hline 593 & 2640 \\
\hline 478 & 2997 \\
\hline 344 & 1418 \\
\hline 291 & 1337 \\
\hline 278 & 1228 \\
\hline 260 & 924 \\
\hline 254 & 978 \\
\hline 216 & 1008 \\
\hline 201 & 666 \\
\hline 196 & 715 \\
\hline 191 & 838 \\
\hline 183 & 588 \\
\hline 145 & 410 \\
\hline 110 & 544 \\
\hline
\end{tabular}

An Evolutionary Theory of Economic Change (with R. Nelson), Harvard University Press, 1982

Science.

"Deliberate Learning and the Evolution of Dynamic Capabilities," (with M. Zollo ${ }^{\text {a }) . ~ O r g a n i z a t i o n ~ S c i e n c e, ~}$
Vol. 13 (2002), pp. 339-351

“Appropriating the Returns from Industrial Research and Development,” (with R. Levin a , A. Klevorick and R.
Nelson), Brookings Papers on Economic Activity (1987), No. 3, pp. 783-820

“Understanding Dynamic Capabilities,” Strategic Management Journal, Vol. 24 (2003), pp. 991-995

"In Search of Useful Theory of Innovation," (with R. Nelson'), Research Policy, Vol. 6 (January 1977), pp. 36-76

"Knowledge and Competence as Strategic Assets," in The Competitive Challenge: Strategies for Industrial Innovation and Renewal, D.J. Teece, ed., (Cambridge, MA: Ballinger, 1987), pp. 159-184

"Understanding Corporate Coherence: Theory and Evidence," (with D. Teece ${ }^{a}$, R. Rumelt and G. Dosi), Journal of Economic Behavior and Organization, Vol. 23 (January 1994), pp. 1-30

"On the Sources and Significance of Interindustry Differences in Technological Opportunities," (with A. Klevorick $^{\mathrm{a}}$, R. Levin, and R. Nelson), Research Policy, Vol. 24 (March 1995), pp. 183-205

"Schumpeterian Competition in Alternative Technological Regimes," Journal of Economic Behavior and Organization, Vol. 5 (September-December 1984), pp. 287-320

"Replication as Strategy," (with G. Szulanski). Organization Science, Vol. 12 (2001), pp. 730-743

“The Satisficing Principle in Capability Learning." Strategic Management Journal, Vol. 21 (2000), pp. 981-996

"Evolutionary Theorizing in Economics," (with R. Nelson ${ }^{\mathrm{a}}$ ). Journal of Economic Perspectives, Vol. 16 (2002), pp. 23-46

"The Co-evolution of Capabilities and Transaction Costs: Explaining the Institutional Structure of Production" (with M. Jacobides ${ }^{\text {a }}$ ), Strategic Management Journal, Vol. 26 (2005), pp. 395-413

"Routines and Other Recurring Action Patterns of Organizations: Contemporary Research Issues," (with M. Cohen $^{a}$, R. Burkhard, G. Dosi, M. Egidi, L. Marengo, M. Warglien), Industrial and Corporate Change, Vol. 5 (1996), pp. 653-698

"Economic 'Natural Selection' and the Theory of the Firm" Yale Economic Essays, Vol. 4 (Spring 1964), pp. 225-272

"Satisficing, Selection and the Innovating Remnant," Quarterly Journal of Economics, Vol. 85 (May 1971), pp. 237-261

“The Economics of Strategic Opportunity" (with J. Denrella and C. Fang), Strategic Management Journal, Vol. 24 (October Special Issue) (2003), pp. 977-990

"Neoclassical vs. Evolutionary Theories of Economic Growth: Critique and Prospectus," (with R. Nelson ${ }^{\mathrm{a}}$ ), Economic Journal, Vol. 84 (December 1974), pp. 886-905

Only publications with 100 citations in WoS included, authors' calculations, May 2015

${ }^{\text {a }}$ First author if not Winter

\section{The (Re-)birth of evolutionary economics}

The early stages of Professor Winter career focus on profit maximization, a story which is well told in Winter (2005). Although his doctoral thesis started as an analysis of corporate spending on $\mathrm{R} \& \mathrm{D}$, he ended up writing about profit maximization and the treatment of firms in economic theorizing and analysis. The starting point was a response to an influential paper by
Milton Friedman, "The Methodology of Positive Economics" (Friedman 1953) In this article, Friedman argued that profit maximization assumption was a fruitful hypothesis, despite the apparent lack of direct observations. This can be to be known as the "as if" maximization, whereby economists could assume that firms act "as if" they do so, even if no observations can be made. After reading the work of the Carnegie school, specifically Cyert, March and Simon, Winter 
(2005: 8) stated that the "as if" assumption leads "beyond objecting to the relevance of some actual observations of firm decision making, and perhaps extends even to the extreme claim that no conceivable direct observations of firm decision making could legitimately cast doubt on the maximization hypothesis." According to Winter (2005: 9), it is "basically a defensive maneuver that serves to protect a seriously flawed theory." Instead, he put forward the notion that business behavior may be based upon simple rules, thus having an explicit grounding in economics based upon behavior reality. Moreover, this emphasized that the macro long-run and systemic effects needed to be complemented with a firm-level understanding of both rules and changes to the rules or to the environment.

The inspiration from the Carnegie school is evident in Winter's article in the Quarterly Journal of Economics (Winter 1971). This paper proposes an analytical model that evoked business behavior in such a way so that innovative entry and competition were mechanisms that tended to drive firms upwards. Essentially, when things are going well, satisficing leads to stability, whereas when things go poorly, satisficing can trigger a response to search for an alternative. Although Winter (2005) professes to be proud of his contribution, in finding a way forward, this paper has instead - contrary to its purpose-been cited for its proof of Friedman's "as if" maximization instead as being seen as the embryo of an alternative approach to economics, built upon an understanding of firm behavior and firm diversity.

This early work was a precursor to a major effort of Professor Winter to develop neo-Schumpeterian, or evolutionary, economics to explain economic change, and the role of heterogeneous firms. The focus was on technical change within firms, as related to heterogeneity in organizational routines and technological opportunities, in an environment with selection mechanisms. In the late 1960s, Professor Winter began an intellectual project with Richard Nelson that would see them make a major contribution to our understanding of the process of economic development. This work involved a re-discovery of the work of Joseph Schumpeter. At the core, this effort was to build up an understanding of the sources of firm differences, focusing on how organizations renew and propagate themselves. This endeavor was based on a deep understanding of the process of technical change within firms - how new products, process and ideas shape the ability of the firm to improve its performance. Their approach sought to shift economics away from the static notions of economic development that had suggested that technical change should be treated as simply a residual in models of economic growth toward a new "evolutionary" approach. Their theorizing about evolutionary economics has greatly impacted the intellectual discussion and provided a theoretical framing for understanding why firm search and learning impacts performance.

An early paper that helped set the direction for this larger project was a report by Winter for The RAND Corporation (Winter 1968), in which Winter argued that because knowledge is heterogenous and dispersed within an organization, a change in the way of production (even in the case of minor adaptations) cannot be represented as simply a shift in the inputoutput combination, as predicted by the production function theory. The change itself requires a learning process that is specific to the routine operations the firm is actually performing and a reconfiguration of the knowledge about operations and concepts that are held by different people in the organization. This learning process is difficult (especially in complex organizations), and its outcomes are highly unpredictable. Winter argues that a theory of the firm which is consistent with a closer-to-reality characterization of the knowledge that is relevant for a firm's production routines - and which defines the identity of the firm - should be historical (as what a firm can do is not hypothetically known given a choice set but is historically determined), dynamic and probabilistic.

In the years following this report, Professor Winter collaborated closely with Richard Nelson on a set of papers and later a book that would together transform the field. In one of the early key papers emerging from this stream, Nelson and Winter (1975) addressed the question of how to explain differences in productivity among industries. They used the "evolutionary" metaphor to do so. Productivity changes because of the introduction of a new technology, a "technological mutation." Productivity differs across industries because of differences in technological opportunities-i.e., the fact that investments in R\&D have more potential and are more productive in some technologies rather than others. Productivity also differs because of differences in the "selection environment." The selection environment shapes how rapidly and broadly a new technology will diffuse within an 
industry. This paper addressed the nature and operation of selection mechanisms, illustrating the differences between market and non-market sectors.

In a related paper in Research Policy, Professor Winter and Nelson further elaborate on the nature of knowledge by introducing the concepts of technological regimes and technological trajectories (1977a). They start from the consideration that engineers and technicians share a common understanding of what can be achieved in improving a way of production, and of means by which such improvements can be achieved. Engineers/technicians have in mind an archetype or model of what a "product" is. That is, they share an idea of what an aircraft is, what is made of, how it is designed and manufactured, and which functions it should perform). Based on this shared knowledge, they form coherent expectations of which principles to apply when solving a problem associated with the introduction of a new production possibility, which outcomes can be expected for solving such a problem, and which objectives can be ultimately achieved in the near future, given the current direction of improvement. Therefore, changes in production techniques are not perfectly elastic to price variations (as predicted by the production function theory), but instead they take place along fairly "ordered" and "delimited" trajectories of improvement ("technological trajectories") shaped by the common basis of knowledge, such as of materials, design principles, technical properties and performance criteria, that is relevant for a certain set of production activities (or "technological regime"). The notion of technological trajectories developed in this paper became an important source of inspiration to later research, especially after its further elaboration in Dosi (1982).

Over the period of the 1970s and early 1980s, Nelson and Winter sought to translate Schumpeter's ideas into a formal simulation model. Their 1977 paper in the American Economic Review (1977b) argued that while Schumpeter's ideas were well recognized and accepted by economists at an "appreciative" level, they were neglected at a "formal" level. They recognized that there is an intrinsic difficulty in formalizing a theory of the firm that is historical, as such a theory cannot make use of the tools of equilibrium analysis. To overcome this obstacle, Nelson and Winter proposed the use of simulation alongside formal modeling, as complementary tool to analytical solution. They describe simulation as a tool to illustrate the implications of alternative assumptions, when these assumptions or, even the questions to ask, are not entirely certain to the researcher. They describe simulation as an explorative tool, which is not exclusive, and which may shed light on relationships the researcher may not have foreseen, and which may demand further investigation.

Nelson and Winter further illustrated the use of simulation to address from a neo-Schumpeterian perspective a central concern in industrial economics, i.e., the determinants of market concentration. In doing so, Nelson and Winter attempt to clarify and explicate the so-called Schumpeterian hypothesis, which states that large firms can benefit in dynamic efficiency as the ability to innovate increases with market power, a commonly tested empirical statement. They point out that if one adopts Schumpeter's dynamic view of competition, market structure is endogenous to innovation, and therefore, the relationship between industry structure and innovation is subject to bidirectional causality. In this paper, they explore how in an industry with rich technological opportunities, firms are more likely to discover important innovations, but also more likely to fail because of the high uncertainty involved. Thus, because of the greater differentials in firm growth rates, market concentration will increase. To illustrate this relationship, they elaborate a model of Schumpeterian competition, which would later appear in the 1982 book and was extended in the 1984 Winter paper (discussed below).

This model suggests a firm's technique, the one that it actually knows and operates, is represented by a given productivity coefficient, which increases over time as the firm carries out R\&D activities with the purpose of either innovating on the current technique, or of imitating the best technique adopted by competitors. Both search processes-to innovate or to imitate-are formalized as random draws from a probabilistic distribution, whose expected value is equal to the latent productivity in the sector (i.e., the level of technological opportunity) for the innovative search, and equal to the average productivity among competitors for the imitative search. The greater the firm's expenditure in R\&D, the more frequently (in a certain time period) the firm will be able to draw from the random distribution of productivity coefficients that represent the outcomes of search. Search is thus not an entirely random process, but follows certain 
trajectories which are shaped by industry conditions (like the level of technological opportunities and the existing state of knowledge in the industry) and firmspecific behavior (especially its own investment in R\&D). Firms make decisions on how much to grow on the basis of an investment rule. In fact, investment in capital (and firm size) is assumed to be proportional to the ratio between price and a marked up unitary production cost, where a firm's desired markup is increasing with its market power. This implies that more profitable firms will grow more rapidly, with a limit to growth imposed by a firm's perception of its market power. Differentials in productivity as an outcome of search processes translate into differentials in growth rates, which will in turn produce variations in market concentration. This is the core element of the Nelson and Winter model of industry evolution, as laid out in full in their 1982 book.

In a later paper, Nelson and Winter (1978) emphasized how their work is related not only to Schumpeter's view of dynamic competition, but also the work of Herbert Simon. Their model can be positioned in Simon's tradition of stochastic models of firm growth, e.g., models that attempt to explain the skewness of the firm size distribution as outcome of variations of Gibrat's law. Gibrat's law states that firm growth rates are independent of firm size (and identically distributed) and therefore generate a lognormal distribution. However, Gibrat's Law predicts a trend toward market concentration that is not often empirically observed. To confront this inconsistency, Simon developed a model that introduced serial correlation in growth rates, a negative relationship between firm growth rates and firm age, and the addition of entry of new firms. Building upon their approach, Nelson and Winter's model attempts to explain how the underlying behavior of a firm (concerning $\mathrm{R} \& \mathrm{D}$ expenditure, investment and output decisions) leads to these variations in Gibrat's Law. In doing so, they provide deeper foundational understanding of how firm size distributions emerge.

In the third of this series of papers on a model of Schumpeterian competition, Nelson and Winter (1982b) extend their basic model by adding a treatment of a "cumulative technology" in which the expected outcome of innovation draws is a function of the firm's current level of productivity. Search is thus local and cumulative. By running "simulation experiments" of the model for these technology regimes, they explore the relationship between the intensity of market competition and the productivity gains of first innovators and later imitators. This model re-interprets the trade-off between static and dynamic efficiency that emerges from Schumpeter's view of the dynamic of competition, as market power generates static inefficiencies but also provides incentives for large firms to invest in $R \& D$, as they can appropriate the monopolistic rents of innovation for a longer time span before being imitated. In other words, dynamic efficiencies could then outbalance static efficiencies due to market power. In the model, a positive relationship between firm size and innovation, as assumed in the Schumpeterian hypothesis, can emerge as an endogenous outcome of the cumulative nature of innovation, as innovators build on their past successes. Whether cumulativeness strengthens the advantage of early innovators (which maintain their first mover advantage) or of followers, which can close the gap more rapidly, depends on the intensity of market competition. In the case of cumulative technology, the advantage of early innovation is more rapidly dissipated in an aggressive competitive market than in an industry where competition is weak, while the advantage of the innovators, although somewhat eroded by competition, is more likely to last in a science-based industry, even in an aggressively competitive market.

Since this work, Professor Winter has developed a range of subsequent modeling papers. The first of these extended the core Nelson and Winter model by incorporating entry dynamics in different technological and competitive regimes (Winter, 1984). This paper focuses adds the entry model, where two simulation runs offer contrasting patterns of industrial dynamics. Under different technological regimes, the paper models and characterizes how firms populate an industry, over time. In a later series of paper with Franco Malerba, Richard Nelson and Luigi Orsenigo, Winter developed a series of "history friendly models" of industry evolution, in which the relationship between innovation, changes in market structure and the broader evolution of an industry has been modeled starting form histories, cases and empirical evidence of specific sectors. Some of these models refer to sectors such as the mainframe and microelectronics industry and semiconductors (Malerba et al. 1999, 2007, 2008a, b).

In these models, entry and entrepreneurship have taken place either at the beginning of an industry, thus 
shaping its subsequent evolution, or at specific moments during industry evolution-such as the ones related to technological discontinuities, in which the newcomers with the new technology challenge the incumbents, that have to switch to the new technology or face decline. The work of Winter and Nelson always starts from the analysis of stylized facts or empirical evidence on firms, sectors, technologies or countries, and on that basis, evolutionary models of heterogeneous firms, characterized by routines and capabilities, and that innovate and adapt to change in different competitive and technological regimes, have been proposed.

The core Nelson and Winter model, and related efforts, have provided an important source of inspiration for other modeling approaches in innovation and entrepreneurship, including the work of Steven Klepper (1996) among others. As documented in Braunerhjelm and Carlsson (2011), Klepper was awarded the 2011 Global Award for Entrepreneurship Research, for his contributions within industrial dynamics, focusing upon the regularities in entry of new producers, spin-offs, innovation and the exit of incumbent firms.

In summary, this first phase has helped lead to a revival of Schumpeterian ideas, based upon the joint work of Professors Nelson and Winter in developing evolutionary economics. This research focuses upon how and why the interactions matter between firms and the environment, based upon an evolutionary approach which links learning and search to the specificities of industries such as variations in technological opportunities.

\section{How the second phase also impacted empirical studies of technical change}

This second phase also involves an attempt to enrich our empirical understanding of technical change. This contribution, with collaborators, is to analyze empirically and theoretically how and why firms act to appropriate returns under different selection environments in different industries, and yet also retain corporate coherence due to learning at the firm level. The treatment of this work in a separate section should not be taken that this work was separated from the theoretical above. This research emerged as a part of a broader set of interactions between Professor Winter and other notable scholars, including among them Chris Freeman, Keith Pavitt, Giovanni Dosi, Richard Nelson, Nathan Rosenberg and David Mowery, working across the Universities of Stanford, Sussex and Yale. This group of scholars in collaboration with their doctoral students and others helped to create a community, that has described as the "Stanford-YaleSussex" consensus, which has been central to the development of the broader field of innovation studies (Fagerberg and Verspagen 2009; Lundvall 2013).

In the late 1970s and early 1980s, Professor Winter helped to initiate a collaborative project between Richard Levin, Alvin Klevorick and Richard Nelson at Yale University on the nature of inter-industry differences with respect to innovation. The project involved a survey of R\&D managers in lines of business at large US-based firms. The survey-which eventually became known as the "Yale Survey"-marked a major shift in our understanding in the nature of innovation.

Although prior research had given significant attention to the level and differences in R\&D expenditures by firms and industries, the literature had left many unanswered questions about what factors shaped these differences. The Yale Survey provided new information about technological opportunities and appropriability conditions in different industries. In doing so, this work spawned a generation of research on the conditions that enhance or retard innovation. Critical to these developments was the Levin et al. (1987) paper on the nature of appropriability. This paper demonstrated - for the first time - that firms rely on a bundle of different appropriability mechanisms. It explained how firms tended to favor informal rather than formal methods of protection, highlighting the importance of secrecy, complementary manufacturing/sales and support and lead times over patents and other legal mechanisms. The paper also demonstrated that patents often worked differently in practice than in theory, as firms found their patents were effective in protecting only a limited set of innovations and that the value of patents was concentrated in a small number of industrial sectors.

The second major paper to emerging from the Yale survey involving Professor Winter was an article in Research Policy, with Klevorick et al. (1995). This paper explored the differences across industries in terms of the level of technological opportunities, by examining the impact and contribution of university 
knowledge to the development of industrial innovation. This paper showed the contribution of universities to industrial innovation across a wide range of sectors rather than simply being localized in a small number of science-based sectors. It also demonstrated that different fields of science impact different industries, allowing for a clearer understanding of how firms draw from a range of knowledge inputs to help them develop new products, processes and services.

These two empirical papers had three major implications, which impacted streams of later research. First, they opened up a range of research questions about firm's strategic use of intellectual property, including the value of patents as a mechanism to not only block others from copying technologies, but also as a vehicle for enabling exchanges in the market for technology. Second, they also helped to raise academic interest in the importance of external sources of knowledge in the innovation process, demonstrating that in many industries, non-commercial sources of knowledge were critical to innovative and entrepreneurial developments. Finally, they offered a research tool-as both data and inspiration-for a range of new research projects. Indeed, the seminal papers of Cohen and Levinthal on absorptive capacity were based on an analysis of the Yale survey data (Cohen and Levinthal 1989, 1990), as were many other important papers in the wider field of innovation and entrepreneurship (Gulati and Singh 1998; Hall and Ziedonis 2001; Shane 2001, 2004).

Another important piece from this period was a joint paper by Professor Winter and Teece et al. (1994) on the degree of coherence among firm's activities. The paper helped to extend understanding of the nature of corporate coherence in the diversification of large firms by measuring and theorizing about why firms' production activities are related. The paper suggests that the corporate coherence is related to the fact that firms learn from one activity and that firms build cumulatively on what they know, developing different-allocative, transactional and administrative-competencies over time. Firms also draw from complementary assets to exploit these related opportunities. The paper also invoked a new measure of coherence that focuses on the relatedness of different production activities and applied this measure to a large sample of US firms. The empirical results demonstrate a high degree of coherence among production activities; this is because, as firms diversify into new sectors, they maintain a relatively constant degree of coherence. The paper has had a major influence on subsequent work on corporate diversification. Professor Winter later extended this work in a joint paper with David Bryce in Management Science (2009), which offered a more refined measure of relatedness.

In summary, we have chosen to highlight how and why this second phase also stimulates empirical studies of technical change at both the industrial level and the firm level. This part of the research agenda has helped to promote an understanding of why learning, appropriability and technological opportunities affects firms in different industries. Firms were shown to use a variety of appropriability mechanisms to guard their innovations, and at the same time, firms exhibit a high level of coherence due to learning defined in terms of three competencies. This work has impacted much later research, especially empirical work, to investigate a rich set of questions, such as the way firms develop competencies to benefit from their inventions; the differences among industries; and the role of external partners and especially universities in stimulating business innovation. Moreover, the research strategy of collecting data on new phenomena directly from respondents became an important one within innovation studies. This has been used by many scholars searching for a deeper understanding of technical change and innovation, and it has also lead to the development and implementation of official statistics, most notably the Community Innovation Survey (CIS).

\section{Routines, capabilities and replication}

The third phase consists of Professor Winter's work on defining how firms develop dynamic capabilities, which is rooted in the evolutionary perspective of routines and replication. This intellectual contribution, when set in relation to debates about routines, learning and managerial choice, provides a deeper understanding of dynamic capabilities not only in large firms but also increasingly studied in the context of smaller, newer firms.

Professor Winter's work has stood at the forefront of strategy over the past 30 years through a series of important contributions to how organizations learn and adapt to change. Although the Nelson and Winter 
(1982a) book was not explicitly targeted to management scholars, the book has become central to attempts to understand how firms' sustain competitive advantage. In particular, the book led to a surge in interest in organizational learning and the role of routines in shaping how firms learn (or not) from experience. It is also a critical foundational text for burgeoning literature on dynamic capabilities, reflected in the fact that the book is among the most cited works in economics and management since its publication.

Part of this impact stems from the rich discussion of "routines" in the book. In Nelson and Winter (1982a), routines were seen as organizational "genes," allowing the organization to reproduce or replicate its practices and activities across different areas and to confront new problems. Nelson and Winter (1982a) described how these routines could both inhibit and enable organization change and adaptation. They also suggested that much organizational life takes place in a semiautomatic way, as routines are embedded in the way things are done inside the organization. By focusing on routines as the means through which organizations renew and reproduce, this work helped to bring attention to concepts such as organizational memory, tacit knowledge and capability formation inside the firm. Nelson and Winter (1982a) also helped to explore the tensions and challenges that organizations face when they respond to external pressures, such as technical change or competitive pressure. They examined how organizational routines limited the range of response options available to managers, and how these routines become "truces" among different political and organizational members.

After the publication of the book, Professor Winter embarked on a broad and influential stream of work on capabilities. For instance, Winter (1987) brings together his interest in capabilities with a discussion about how firms' protect their innovative assets. This chapter helped to further identify the mechanisms that enable organizations to capture value from their knowledge base, suggesting that tacit knowledge rather than codified knowledge is critical to appropriation. The paper also discusses different properties of knowledge-tacitness, complexity, articulated, observability - held by the firm and how the transfer of these different types of knowledge impedes or enables learning within and outside the firm.
As part of a workshop at the Santa Fe Institute in 1995, a group of authors (including Winter) explored the nature and definition of routines (Cohen et al. 1996). As part of the discussion, the authors working on routines from difference perspectives attempted to define the notion of a routine, settling on "an executable capability for repeated performance in some context that learning by an organization in response to selective pressures" (p. 683), and this definition has had an impact in shaping notions of routines in the wider management literature.

Professor Winter's interest in capabilities has also focused on the question of when organizations pull back and stop investing resources and managerial attention to continual learning in an area. Winter (2000) explored the question of when "overt learning stop[s]" in organizations. In this paper, he stresses the costs of building up a capability to the firm and how firms will stop invest in capability when the incremental costs of pursuing it are likely to exceed the benefits gained from it. New capabilities are often primitive and difficult to evaluate. Managers do not know which evolutionary path will be the most productive and so they rely on past experience to guide them. At some point, there may be a general waning of returns to continuous improvement. As a result, firms may stop learning in an area, as the trend line of improvement is subject to decreasing rather than negative returns. Winter points out that these patterns of non-learning can be overcome by external shocks or even the renewal from within of the capability itself through vicarious and congenital learning.

A critical contribution of Professor Winter to the area of capabilities was his joint paper with Maurizio Zollo in Organization Science (Zollo and Winter 2002). This paper is among the most cited papers in management since its publication. The paper investigates the mechanisms through which organizations develop dynamic capabilities. It highlights the importance of three different learning mechanisms, focusing on the role of experience accumulation, knowledge articulation and knowledge codification that lead to the creation and evolution of dynamic capabilities. Using this framework, the authors outline a "cyclical view" of the evolution of organizational knowledge where knowledge is generated, selected, replicated and retained by the organization. They also give attention to the role of managerial choice in 
deliberately shaping the organization's capabilities and how different forms of articulation and codification of knowledge may facilitate replication and retention of capabilities across the organization.

In later work, Winter (2003) explored varying levels of dynamic capabilities, differentiating between "zero-level," "first-order" or "operational" capabilities which involve allowing the organization to "earn its living in the present," allowing it to perform its normal, everyday activities. In contrast, dynamic or "second-order" capabilities involve changes in operational routines, allowing firms to create new products, processes or routines. Although investing in dynamic capabilities can help firms meet competitive changes, Winter (2003) suggests that such changes also entail costs, as change can be disruptive and the benefits of these investments may not materialize. By highlighting the different levels of capabilities and the costs and benefits that may be associated with them, this paper helped to inspire a range of related work on different types of capabilities and the competitive implications of firm's investments in them.

Building on these insights on the nature of capabilities, Winter turned to the question of the relationship between transaction costs and capabilities and how they shape vertical scope. In a key paper co-authored with Jacobides and Winter (2005), he explored how the nature of capabilities in the value chain gives rise to vertical specialization, suggesting a dynamic, coevolutionary view of firm boundaries. In particular, the paper suggests that transaction costs are not fixed exogenously, but a product of conscious choices by firms, and through the distribution of capabilities within the institutional setting of the industry. The paper offers a rich account of how different evolutionary mechanisms dynamically shape relationships among capabilities, transactions costs and vertical scope.

Professor Winter, again with co-author Michael Jacobides, has returned to these themes his paper in Organization Science (2012) that explores attempts to integrate research from transaction cost economics with capabilities view, highlighting new areas for theorizing and research which move beyond the level of the firm. Areas for research include agency, industry architecture and business models, because they link the development of firm capabilities with the shifting nature of firm boundaries due to structural features, within a broader understanding of organizational economics.
In addition, Professor Winter collaborated with colleagues on a book on dynamic capabilities (Helfat et al. 2009), which has helped to develop greater understanding and interest in this area of strategy. Moreover, Professor Winter has worked with Constance Helfat on a paper on differences between operational and dynamic capabilities (Helfat and Winter 2011). While the distinction between operational and dynamic capabilities will remain a bit blurry due to the ever-changing environment, they stress that there are important distinctions to be made. Hence, they stress that researchers should develop clearer categories, acknowledge time-frames and levels of analysis in developing categories, and also focus upon non-radical changes and existing businesses, as well as rapidly changing ones.

Over the past few years, Professor Winter has engaged in a lively debate with critics of the capabilities approach, in particular Felin and Foss (2005), who argued that the approach of Winter and colleagues has given too little attention to the "micro-foundations" of capabilities. In particular, Felin and Foss point to the limited role of individuals and individual motivations in shaping more general patterns of organizational behavior. As part of responding to this criticism and others, Professor Winter wrote a number of articles exploring the notion of capabilities and the epistemological roots of the research area (Foss et al. 2012; Winter 2011, 2012, 2013). In these papers, he has also responded directly to criticism and sought to find common ground with critics about future research directions.

Professor Winter's work on capabilities has also focused on the replication of routines in organizations. This work builds upon the notion of routines in the Nelson and Winter book and his 1995 book chapter on the "Four Rs of Profitability" (Winter 1995), but he extends these concepts to try to understand how organizations' propagate their routines across time and space. In a 2001 Organization Science paper with Gabriel Szulanski, Professor Winter developed a theory of replication strategy, exploring how organizations create a "template" and transfer knowledge from this template across different units (Winter and Szulanski 2001). At the core of the approach are ways to describe how organizations build capabilities to replicate operational routines to enable large-scale and rapid expansion, allowing them to increase the scale and scope of their exploitation from their core knowledge base. 
In recent years, Professor Winter (and co-authors Szulanski, Ringov and Jensen) have extended this work in an empirical paper on the survival units US home office market (Winter et al. 2012). Their research focused upon units of a large, established nonfood franchise chain, and their results suggest that some types of deviations from the template increase the risk of unit failure. Given the diversity of environments studied while other variables are kept constant, the authors suggest a need to reconsider the recommendation to adapt to fit new host environments, and instead suggest that replicating operational routines in this franchise chain can enable rapid expansion and reduce failure.

In summary, this third phase of his career has more focused on topics related to dynamic capabilities, replication and boundaries of the firm has been highly influential within management research, and stimulated a wide and lively debate on the types of capabilities and on firm reactions to different types of environments. By focusing on capabilities - their development and propagation-Professor Winter has created a richer understanding of the nature of value creation and capture within organizations, helping to advance our understanding of entrepreneurial renewal (and decline) within established organizations.

\section{Conclusion}

Professor Sidney G. Winter is a remarkably talented and influential scholar, well known for his contributions in developing theoretical frameworks and empirical evidence about evolutionary processes at the level of firms and of industries. This paper has defined his intellectual contributions in terms of three phases of his research career, discussed above.

His work has thus provided entrepreneurship research with a strong and coherent intellectual framework for understanding why differences in firms and industries matter for performance and the evolutionary pathways. Moreover, notions such as dynamic capabilities, technical opportunities and environmental selection mechanisms are used within entrepreneurship research, and especially those interested in what is known as Schumpeterian creation of opportunities, as opposed to Kirznerian development of opportunities.

The evolutionary economics approach has been at the center of Winter's long-standing collaboration with Richard Nelson, and impacted our understanding of the connections between routines and decision making in firms with the selection environments of industries. Moreover, Winter has greatly impacted the strategy literature, especially through his exploration of routines and dynamic capabilities at the firm level. This work has tackled fundamental questions about how and why firms learn-or stop learning-in different environments, as well as how capabilities are related to the appropriation of returns on investments into R\&D and into related innovative activities. Winter's research has combined careful empirical studies and simulations with theoretical developments, across his multiple intellectual contributions.

His conceptualization across many areas has had an impact on many related fields, because the research demonstrates that differential firm-level attributes of learning and search for knowledge will interact with selection mechanisms in the industry in determining outcomes. This impressive research agenda has opened up a strong theoretical and empirical understanding of how managerial choices made, capabilities are organized, and knowledge gathered, will matter for long-term outcomes in terms of both innovations and growth. Professor Winter's commitment to sustained and civilized intellectual debate, and his investment of time and effort helping to support and develop people and institutions to further these ideas is an enduring feature of his career and an essential part of his contribution to the wider academic community.

Acknowledgments This paper has benefited by detailed and insightful comments from Professor Winter on an earlier draft. We have also received comments, support and advice from Richard Nelson, Franco Malerba and Orietta Marsili. All errors and omissions remain the responsibility of the authors.

Open Access This article is distributed under the terms of the Creative Commons Attribution 4.0 International License (http:// creativecommons.org/licenses/by/4.0/), which permits unrestricted use, distribution, and reproduction in any medium, provided you give appropriate credit to the original author(s) and the source, provide a link to the Creative Commons license, and indicate if changes were made.

\section{References}

Braunerhjelm, P., \& Carlsson, B. (2011). Steven Klepper: Recipient of the 2011 Global Award for Entrepreneurship Research. Small Business Economics, 37, 131-140. 
Braunerhjelm, P., \& Henrekson, M. (2009). Awarding entrepreneurship research: A presentation of the global award. Entrepreneurship, Theory and Practice, 33(3), 809-814.

Bryce, D. J., \& Winter, S. G. (2009). A general interindustry relatedness index. Management Science, 55(9), 1570-1585.

Carlsson, B., Braunerhjelm, P., McKelvey, M., Olofsson, C., Persson, L., \& Ylinenpää, H. (2013). The evolving domain of entrepreneurship research. Small Business Economics, 41, 913-930.

Cohen, M. D., Burkhart, R., Dosi, G., Egidi, M., Marengo, L., Warglien, M., \& Winter, S. (1996). Routines and other recurring action patterns of organizations: contemporary research issues. Industrial and Corporate Change, 5(3), 653-698.

Cohen, W., \& Levinthal, D. (1989). Innovation and learning: the two faces of R\&D. Economic Journal, 99(3), 569-596.

Cohen, W. M., \& Levinthal, D. A. (1990). Absorptive capacity: A new perspective of learning and innovation. Administrative Science Quarterly, 35(1), 128-152.

Dosi, G. (1982). Technological paradigms and technological trajectories: A suggested interpretation of the determinants and directions of technical change. Ressearch Policy, 11(3), 147-162.

Fagerberg, J., \& Verspagen, B. (2009). Innovation studies-The emerging structure of a new scientific field. Research Policy, 38, 218-233.

Felin, T., \& Foss, N. J. (2005). Strategic organization: a field in search of micro-foundations. Strategic Organization, 3(4), 441-455.

Foss, N. J., Heimeriks, K. H., Winter, S. G., \& Zollo, M. (2012). A hegelian dialogue on the micro-foundations of organizational routines and capabilities. European Management Review, 9(4), 173-197.

Friedman, M. (1953). The methodology of positive economics, essays in positive economics. Chicago: The University of Chicago Press.

Gulati, R., \& Singh, H. (1998). The architecture of cooperation: Managing coordination costs and appropriation concerns in strategic alliances. Administrative Science Quarterly, 43, 781-814.

Hall, B. H., \& Ziedonis, R. H. (2001). The patent paradox revisited: an empirical study of patenting in the US semiconductor industry, 1979-1995. Rand Journal of Economics, 32(1), 101-128.

Helfat, C. E., Finkelstein, S., Mitchell, W., Peteraf, M., Singh, H., Teece, D., \& Winter, S. G. (2009). Dynamic capabilities: Understanding strategic change in organizations. Wiley.

Helfat, C. E., \& Winter, S. G. (2011). Untangling dynamic and operational capabilities: strategy for the $(\mathrm{N})$ ever-changing world. Strategic Management Journal, 32(11), 1243-1250.

Jacobides, M. G., \& Winter, S. G. (2005). The co-evolution of capabilities and transaction costs: Explaining the institutional structure of production. Strategic Management Journal, 26(5), 395-413.

Jacobides, M. G., \& Winter, S. G. (2012). Capabilities: Structure, agency, and evolution. Organization Science, 23(5), 1365-1381.
Klepper, S. (1996). Entry, exit, growth and innovation over the product life cycle. American Economic Review, 86(3), 562-583.

Klevorick, A. K., Levin, R., Nelson, R., \& Winter, S. (1995). On the sources and significance of inter-industry differences in technological opportunities. Research Policy, 24, 185-205.

Levin, R. C., Klevorick, A. K., Nelson, R. R., \& Winter, S. G. (1987). Appropriating the returns from industrial-research and development. Brookings Papers on Economic Activity, 3, 783-831.

Lundvall, B.-A. (2013). Innovation studies: A personal interpretation of the state of the art. In J. Fagerberg, B. R. Martin, \& E. S. Anderson (Eds.), Innovation Studies: Evolution and Future Challenges (pp. 21-70). Oxford: Oxford University Press.

Malerba, F., Nelson, R., Orsenigo, L., \& Winter, S. (1999). History friendly models of industry evolution: the case of the computer industry. Industrial and Corporate Change, 8(1), 3-40.

Malerba, F., Nelson, R., Orsenigo, L., \& Winter, S. (2007). Demand, innovation, and the dynamics of market structure: The role of experimental users and diverse preferences. Journal of Evolutionary Economics, 17(4), 371-399.

Malerba, F., Nelson, R., Orsenigo, L., \& Winter, S. (2008a). Public policies and changing boundaries of firms in a "history-friendly" model of the co-evolution of the computer and semiconductor industries. Journal of Economic Behavior \& Organization, 67(2), 355-380.

Malerba, F., Nelson, R., Orsenigo, L., \& Winter, S. (2008b). Vertical integration and disintegration of computer firms: a history-friendly model of the coevolution of the computer and semiconductor industries. Industrial and Corporate Change, 17(2), 197-231.

Nelson, R. R., \& Winter, S. G. (1975). Growth theory from an evolutionary perspective-Differential productivity puzzle. American Economic Review, 65(2), 338-344.

Nelson, R. R., \& Winter, S. G. (1977a). Search of useful theory of innovation. Research Policy, 6(1), 36-76.

Nelson, R. R., \& Winter, S. G. (1977b). Simulation of Schumpeterian competition. American Economic Review. Papers and Proceedings, 67, 271-276.

Nelson, R. R., \& Winter, S. G. (1978). Forces generating and limiting concentration under schumpeterian competition. Bell Journal of Economics, 9, 524-548.

Nelson, R. R., \& Winter, S. (1982a). An evolutionary theory of economic change. Cambridge, MA: Harvard University Press.

Nelson, R. R., \& Winter, S. G. (1982b). The Schumpeterian tradeoff revisited. American Economic Review, 72(1), $114-132$.

Shane, S. (2001). Technology regimes and new firm formation. Management Science, 47(9), 1173-1190.

Shane, S. (2004). Encouraging university entrepreneurship? The effect of the Bayh-Dole Act on university patenting in the United States. Journal of Business Venturing, 19(1), 127-151.

Teece, D. J., Rumelt, R., Dosi, G., \& Winter, S. (1994). Understanding corporate coherence-Theory and evidence. Journal of Economic Behavior \& Organization, 23(1), 1-30. 
Winter, S. G. (1968). Toward a neo-Schumpeterian theory of the firm. Santa Monica, CA: Rand Corporation Publication, P-3802.

Winter, S. G. (1971). Satisficing, selection and the innovating remnant. Quarterly Journal of Economics, 85(2), 237-261.

Winter, S. G. (1984). Schumpeterian competition in alternative technological regimes. Journal of Economic Behavior \& Organization, 5, 287-320.

Winter, S. (1987). Knowledge and competence as strategic assets. In D. Teece (Ed.), The competitive challengeStrategies for industrial innovation and renewal. Cambridge MA: Ballinger.

Winter, S. G. (1995). Four Rs of profitability: Rents, resources, routines, and replication. Berlin: Springer.

Winter, S. G. (2000). The satisficing principle in capability learning. Strategic Management Journal, 21(10-11), 981-996.

Winter, S. G. (2003). Understanding dynamic capabilities. Strategic Management Journal, 24(10), 991-995.

Winter, S. G. (2005). Developing evolutionary theory for economics and management. In M. Hitt \& K. G. Smith (Eds.),
The oxford handbook of management theory. Oxford: Oxford University Press.

Winter, S. G. (2011). Problems at the foundation? Comments on Felin and Foss. Journal of Institutional Economics, 7(2), 257.

Winter, S. G. (2012). Capabilities: Their origins and ancestry. Journal of Management Studies, 49(8), 1402-1406.

Winter, S. G. (2013). Habit, deliberation, and action: Strengthening the microfoundations of routines and capabilities. The Academy of Management Perspectives, 27(2), 120-137.

Winter, S. G., \& Szulanski, G. (2001). Replication as strategy. Organization Science, 12(6), 730-743.

Winter, S. G., Szulanski, G., Ringov, D., \& Jensen, R. J. (2012). Reproducing knowledge: Inaccurate replication and failure in franchise organizations. Organization Science, 23(3), 672-685.

Zollo, M., \& Winter, S. G. (2002). Deliberate learning and the evolution of dynamic capabilities. Organization Science, 13(3), 339-351. 